\title{
PERBANDINGAN EFEKTIFITAS EKSTRAK ETANOL 96\% AKAR DAN DAUN KUMIS KUCING (Orthosiphon stamineus) TERHADAP PENURUNAN GLUKOSA DARAH MENCIT (Mus musculus)
}

\author{
Syarifah Nora Andriaty, ${ }^{1}$ Faidil Akbar ${ }^{1}$, Abdul Wahab ${ }^{1}$ \\ ${ }^{1}$ Prodi Pendidikan Dokter, Fakultas Kedokteran, Universitas Abulyatama
}

\begin{abstract}
Comparison Effectiveness of Extract Ethanol 96\% Root and Leaves Kumis Kucing (Orthosiphon Stamineus) Against Reduction of Blood Glucose Mice (Mus Musculus). Orthosiphon stamineus is known as kumis kucing, a traditional plant which used widely in many diseases, including diabetes mellitus. Riset Kesehatan Dasar (Riskesdas) 2018 shown the prevalence of diabetes mellitus is getting higher from $6,9 \%$ becoming 8,5\%. Objective: To compared the effectiveness of $96 \%$ ethanol extract between leaves and roots of kumis kucing (Orthosiphon stamineus) to decreased mice's (Mus musculus) blood glucose levels. Method: This was an experimental study, 25 mice were induced alloxan in I.P, leaf extract and root of kumis kucing were administered at $35 \mathrm{mg}$ and $50 \mathrm{mg} / 20 \mathrm{gBB} /$ day doses for 7 days. Result: The result showed that the extract of the leaves of kumis kucing dose $35 \mathrm{mg}$ and $50 \mathrm{mg} / 20 \mathrm{gBB} /$ day decreased the blood glucose level $35.45 \%$ and $41.61 \%$, whereas the root extract of kumis kucing dose $35 \mathrm{mg}$ and $50 \mathrm{mg} / 20 \mathrm{gBB} /$ day as much as $25.5 \%$ and 29, $19 \%$. Paired t test obtained $\mathrm{p}$ value $=0.000$, it's mean there is a significant decreasing in blood glucose levels. Conclusion: $96 \%$ ethanol extract of kumis kucing's leaves with dosage $50 \mathrm{mg} / 20 \mathrm{gBB} /$ day reduce $41,6 \%$ of the blood glucose level.
\end{abstract}

Keywords: Leaf and root extract of kumis kucing, blood glucose levels, diabetes mellitus.

\begin{abstract}
Abstrak: Perbandingan Efektifitas Ekstrak Etanol 96\% Akar Dan Daun Kumis Kucing (Orthosiphon stamineus) Terhadap Penurunan Glukosa Darah Mencit (Mus musculus) Orthosiphon stamineus yang dikenal dengan nama kumis kucing adalah tanaman herbal yang banyak digunakan dalam berbagai penyakit, termasuk diabetes melitus. Tanaman ini sangat mudah dijumpai di Indonesia. Hasil Riset Kesehatan dasar (Riskesdas) 2018 diperoleh data prevalensi diabetes melitus meningkat dari 6,9\% menjadi 8,5\%. Membandingkan efektivitas ekstrak etanol 96\% daun dengan akar kumis kucing (Orthosiphon stamineus) terhadap penurunan kadar glukosa darah mencit (Mus musculus). Jenis penelitian ini adalah eksperimental, 25 ekor mencit diinduksikan aloksan secara I.P, ekstrak daun dan akar kumis kucing masing-masing diberikan dengan dosis $35 \mathrm{mg}$ dan $50 \mathrm{mg} / 20 \mathrm{gBB} /$ hari secara oral selama 7 hari. Hasil: Ekstrak daun kumis kucing dosis $35 \mathrm{mg}$ dan $50 \mathrm{mg} / 20 \mathrm{gBB} /$ hari menurunkan kadar glukosa darah mencit $35,45 \%$ dan $41,61 \%$, sedangkan eskstrak akar kumis kucing dosis $35 \mathrm{mg}$ dan $50 \mathrm{mg} / 20 \mathrm{gBB} /$ hari sebanyak 25,5\% dan 29,19\%. Uji t berpasangan didapatkan nilai $\mathrm{p}=0.000$, artinya terdapat perbedaan penurunan kadar glukosa darah mencit yang signifikan. Kesimpulannya yaitu Ekstrak etanol $96 \%$ dari daun kumis kucing dosis $50 \mathrm{mg} / 20 \mathrm{gBB} /$ hari memiliki efek antidiabetik yang lebih tinggi daripada ekstrak akar kumis kucing.
\end{abstract}

Kata Kunci: Ekstrak daun dan akar kumis kucing, kadar glukosa darah mencit, diabetes melitus. 


\section{PENDAHULUAN}

Diabetes

melitus

merupakan gangguan metabolik kompleks yang ditandai dengan peningkatan kadar gula darah menahun akibat kerusakan pada sel penghasil insulin, penurunan sensitivitas insulin atau keduanya (American Diabetes Association, 2017) Diabetes melitus juga dipengaruhi oleh berbagai faktor, seperti pola hidup tidak sehat, riwayat keluarga, usia, jenis kelamin, berat badan lahir, obesitas, hipertensi, dislipidemia, kurangnya aktifitas fisik, diet yang tidak seimbang, merokok, dan stres. Diabetes melitus memerlukan perawatan medis yang berkelanjutan untuk mencegah komplikasi akut dan mengurangi resiko jangka panjang (PERKENI, 2015).

Berdasarkan data dari International Diabetes Federation (IDF), prevalensi pasien diabetes melitus di dunia tahun 2017 berjumlah 425 juta jiwa pada orang dewasa. ${ }^{3}$ Persentase diabetes pada orang dewasa sebanyak 8,6\% (1 diantara 11 orang dewasa di dunia menderita diabetes). Pada tahun 2045, pasien diabetes melitus diperkirakan akan meningkat menjadi 629 juta jiwa orang dewasa dengan tingkat kejadian 1 diantara 10 orang dewasa di dunia menderita diabetes melitus (WHO, 2016).

Pada tahun 2015, Indonesia menduduki peringkat ke-7 sebagai negara yang memiliki penderita diabetes melitus terbanyak di dunia. Di Asia Tenggara, Indonesia menempati peringkat ke-2 sebagai penyebab kematian tertinggi karena diabetes melitus setelah Sri Langka (WHO, 2016). Riset Kesehatan Dasar (RISKESDAS) 2013 menunjukan prevalensi diabetes melitus di Indonesia cenderung meningkat. Pada tahun 2007 penderita diabetes melitus di Indonesia sebesar $5,7 \%$ dan pada tahun 2013 menjadi 6,9\% dengan jumlah perkiraan penderita diabetes melitus sebanyak 12 juta jiwa, Toleransi Glukosa Terganggu (TGT) sebanyak 52 juta jiwa, dan Glukosa Darah Puasa Terganggu (GDPT) sebanyak 64 juta jiwa. $^{5}$

Kumis kucing (Orthosiphon stamineus) merupakan tanaman umum yang dijumpai di Asia Tenggara terutama di Indonesia, Malaysia, Thailand, Vietnam dan Myanmar. Tanaman ini dapat tumbuh sempurna dengan cahaya matahari penuh dan pada daerah beriklim hangat, namun juga bisa tumbuh di tanah yang lembab (Lee $\mathrm{HJ}$, et al, 2015). Tingginya bisa mencapai 30-150 cm dan memiliki bunga berwarna putih, biru atau ungu. Ketika bunganya mekar, benang sari dan putiknya melebar jauh melampaui kelopak bunga yang menyerupai kumis kucing (Adnyana IK, dkk, 2013). Tanaman ini sering digunakan sebagai tumbuhan obat tradisional, di Indonesia tanaman tersebut dapat dijadikan teh (Lee $\mathrm{HJ}$, et al, 2015). Kumis kucing (Orthosiphon stamineus) mempunyai efek sebagai anti diabetes, anti inflamasi, dan anti angiogenik (Adnyana IK, dkk, 2013).

Studi fitokimia melaporkan, terdapat sekitar 116 senyawa yang diisolasikan dari tumbuhan kumis kucing (Orthosiphon stamineus) diklasifikasikan sebagai monoterpen, diterpen, triterpen, saponin, flavonoid, minyak atsiri dan asam organik (Singh, et al, 2015). Sedangkan studi farmakologi untuk ekstrak utuh, tingkur, fraksi terpilih atau senyawa terpilih yang telah diisolasi dari tumbuhan tersebut menunjukkan terdapat efek anti oksidan, anti tumor, diuretik dan nefroprotektif, anti diabetes, anti hipertensi, anti inflamasi, anti mikroba, anti obesitas dan hepatoprotektif. Penggunaan kumis kucing (Orthosiphon stamineus) secara tradisional, memenuhi bukti ilmiahnya dalam aspek fitokimia, farmakologi, toksikologi, maupun klinis. Lee $\mathrm{HJ}$ et al., menyatakan dalam jurnalnya bahwa ekstrak heksana dari kumis kucing (Orthosiphon stamineus) dapat meningkatkan ekspresi messenger Ribonucleic Acid (mRNA) insulin dan mencegah glucotoxicity yang diinduksi dengan pengobatan 3 hari pada kondisi hiperglikemia. Hal ini terkait dengan aktivasi phosphoinositede 3-kinase (PI-3K) dan V-akt murine thymoma viral oncogene homolog (AKT) (Lee HJ, et al, 2015). School of Pharmaceutical Sciences, Universiti Sains Malaysia meneliti bahwa tumbuhan kumis kucing(Orthosiphon stamineus) dapat menghambat a-glukosidase dan menjadi salah satu mekanisme dari ekstrak kumis kucing (Orthosiphon stamineus) yang memberikan efek anti diabetesnya. Selanjutnya, temuan ini menunjukkan bahwa ekstrak etanol $50 \%$ dari kumis kucing(Orthosiphon stamineus) dapat dianggap sebagai agen potensial untuk pengelolaan diabetes melitus (Mohamed EA, 2015).

Pada tahun 2017, Fauzan melakukan uji efek ekstrak etanol $70 \%$ dari daun kumis kucing (Orthosiphon stamineus) dan Maharani melakukan uji efek ekstrak etanol $70 \%$ dari akar kumis kucing (Orthosiphon stamineus) terhadap penurunan gula darah 
pada tikus putih jantan galur wistar (Rattus norvegicus), kedua uji tersebut memperoleh hasil bahwa ekstrak etanol $70 \%$ dari akar dan daun tumbuhan tersebut dapat menurunkan kadar gula darah terhadap tikus putih jantan galur wistar (Rattus norvegicus).

\section{METODE}

Jenis dan desain penelitian ini adalah eksperimental dengan menggunakan metode pre and post test with controlled group design yang merupakan bagian dari true experimental design yang dapat mengontrol semua variabel dan dapat mempengaruhi jalannya eskperimen. Syarat dari true experimental design sampelnya harus dipilih secara random dari populasi tertentu dan memiliki kelompok kontrol.Karena mengambil metode pre and post test with controlled group design, data diambil sebelum dan sesudah perlakuan pada tiap kelompok mencit.

\section{Alat dan Bahan Penelitian}

Alat yang digunakan dalam penelitian ini terdiri dari glukocek, sonde lambung, spuit $1 \mathrm{cc}$, neraca analitik, gunting, gelas ukur, kandang mencit, dan gelas ukur. Bahan yang digunakan dalam penelitian terdiri dari daun dan akar (Orthosiphon stamineus), aloksan, Aquades, air, pakan standard an etanol $96 \%$.

\section{Hewan Uji Penelitian}

Pengambilan sampel secara probability sampling atau pengambilan sampel secara acak dengan jenis pengambilan sampel secara proportionate stratified random sampling. Untuk menentukan minimal sampel, peneliti menggunakan rumus Federer dengan persamaan :

$$
(\mathrm{t}-1)(\mathrm{r}-1) \geq 15
$$

Keterangan:

$t$ : jumlah perlakuan

$r$ : besar sampel tiap kelompok

Penelitian dilakukan dalam bentuk in vivo menggunakan 25 ekor mencit (Mus musculus) dengan 5 ulangan. Mencit diadaptasikan terlebih dahulu selama 14 hari sebelum diberikan perlakukan, selama penelitian mencit dibelikan minuman dan pakan standar.

\section{Pembuatan Ekstrak Kumis Kucing kucing(Orthosiphon stamineus)}

Pembuatan ekstrak kumis kucing (Orthosiphon stamineus) dilakukan di Laboratorium Kimia Fakultas Keguruan dan Ilmu Pendidikan Universitas Syiah Kuala.Bagian yang digunakan adalah daun dan akar yang masing-masingnya seberat 2 $\mathrm{kg}$. Setelah proses pengeringan, simplisia dari daun dan akar kumis kucing (Orthosiphon stamineus) diekstraksikan dengan etanol 96\% menggunakan maserator dan dilanjutkan dengan evaporasi. Ekstrak dilakukan uji fitokimia berupa senyawa flavonoid dan saponin.

\section{Pemberian Aloksan dan Ekstrak}

Aloksan seberat $30 \mathrm{mg}$ dilarutkan dengan aquades dan diberikan secara oral menggunakan sonde lambung.Dosis ekstrak etanol $96 \%$ daun dan akar kumis kucing (Orthosiphon stamineus) dibagi dua, dosis, pertama $35 \mathrm{mg} / 20 \mathrm{~g}$ BB/hari sedangkan yangg kedua $50 \mathrm{mg} / 20 \mathrm{~g} \mathrm{BB} /$ hari untuk masing -masing ekstrak

Tabel 1. Dosis Perlakuan

\begin{tabular}{lll}
\hline Perlakuan & Pemberian & Dosis \\
\hline Kontrol - & Aquades & $0.2 \mathrm{ml}$ \\
\hline P1 & EDKK & $35 \mathrm{mg}$ \\
\hline P2 & EDKK & $50 \mathrm{mg}$ \\
\hline P3 & EAKK & $35 \mathrm{mg}$ \\
\hline P4 & EAKK & $50 \mathrm{mg}$ \\
\hline
\end{tabular}

Keterangan

*Ekstrak Daun Kumis Kucing

**Ekstrak Akar Kumis Kucing

1. Perbandingan Peningkatan Kadar Glukosa Darah Mencit (Mus musculus)

Persentase Peningkatan $=\frac{P-Q}{Q} X 100 \%$ Keterangan :

$\mathrm{P}=$ Rata-rata kadar glukosa darah mencit setelah induksi aloksan

$\mathrm{Q}=$ Rata-rata kadar glukosa darah mencit sebelum induksi aloksan

2. Perbandingan Penurunan Kadar Glukosa Darah Mencit (Mus musculus)

Persentase Penurunan $=\frac{Q-P}{Q} X 100 \%$ Keterangan:

$\mathrm{Q}=$ Rata-rata kadar glukosa darah mencit kontrol negatif

$\mathrm{P}=$ Rata-rata kadar glukosa darah mencit setelah pemberian ekstrak 


\section{Analisis Data}

Hasil data yang telah diperoleh akan diaplikasikan menggunakan software SPSS, data yang diperoleh dilakukan uji ShapiroWilk untuk uji normalitasnya sebelum uji

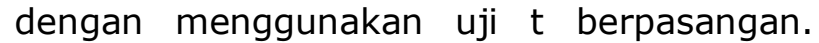
Pengumpulan data diambil sebelum diberikan perlakuan dan setelah diberikan perlakuan, data yang diperoleh akan dibandingkan.

HASIL

Hasil Uji Fitokimia

Berdasarkan hasil uji fitokimia ekstrak daun dan akar kumis kucing (Orthosiphon stamineus) diperoleh :

Tabel 2.Hasil Uji Fitokimia Ekstrak Daun

\begin{tabular}{ccc}
$\begin{array}{l}\text { dan Akar } \\
\text { (Orthosiphon }\end{array}$ & Ktamis & Kucing \\
\hline Ekstrak & Senyawa & Keterangan
\end{tabular}

\begin{tabular}{lll}
\hline $\begin{array}{l}\text { Ekstrak } \\
\text { daun } \\
\text { kumis } \\
\text { kucing }\end{array}$ & Flavonoid & Positif \\
\cline { 2 - 3 } \cline { 2 - 3 } $\begin{array}{l}\text { Ekstrak } \\
\text { akar kumis } \\
\text { kucing }\end{array}$ & Saponin & Positif \\
\cline { 2 - 3 } & Saponin & Negatif \\
\hline
\end{tabular}

Flavonoid dan saponin merupakan salah satu senyawa metabolik sekunder penting yang berperan dalam meregulasikan kadar glukosa darah. Uji fitokimia yang dilakukan hanya mencari senyawa flavonoid dan saponin.

\section{Kadar Glukosa Darah Mencit (Mus musculus)}

Data yang ditabulasi merupakan kadar glukosa darah mencit sebelum diinduksikan aloksan, setelah (pretest) diinduksikan aloksan dan setelah (posttest) diberikan perlakuan. Terdapat 5 ulangan dari masing-masing perlakuan sebagai berikut:

Tabel 3. Kadar Glukosa Darah Mencit Sebelum Diinduksikan Aloksan

\begin{tabular}{lllllll}
\hline \multirow{2}{*}{ Perlakuan } & \multicolumn{2}{l}{ Ulangan } & & & \\
\cline { 2 - 6 } & U1 & U2 & U3 & U4 & U5 & \\
\hline Kontrol - & 101 & 110 & 119 & 97 & 102 & $105,8 \pm 8,75$ \\
\hline P1 & 104 & 105 & 111 & 102 & 107 & $105,8 \pm 3,42$ \\
\hline P2 & 109 & 104 & 108 & 100 & 100 & $104,2 \pm 4,26$ \\
\hline P3 & 113 & 110 & 102 & 109 & 99 & $106,6 \pm 5,85$ \\
\hline P4 & 98 & 112 & 106 & 101 & 104 & $104,2 \pm 5,31$ \\
\hline
\end{tabular}

Data dari tabel 3 selanjutnya dilakukan uji shapiro wilk menggunakan software SPSS, didapati $\mathrm{p}=>0,05$ yang menunjukan distribusi data normal. Data tersebut menjadi parameter untuk melihat peningkatan kadar glukosa darah mencit setelah diinduksikan aloksan.

\begin{tabular}{|c|c|c|c|c|c|c|}
\hline bel & $\begin{array}{l}\text { Kada } \\
\text { Setel } \\
\text { Aloks }\end{array}$ & $\begin{array}{l}\mathbf{G} \\
\mathbf{h} \\
\mathbf{n}\end{array}$ & $\begin{array}{l}\text { KOS } \\
\text { ret }\end{array}$ & t) & $\begin{array}{l}\text { ah } \\
\text { indu }\end{array}$ & $\begin{array}{l}\text { Mencit } \\
\text { aksikan }\end{array}$ \\
\hline \multirow{2}{*}{ Perlakuan } & \multicolumn{5}{|c|}{ Ulangan } & \multirow{2}{*}{ Rata-rata } \\
\hline & U1 & U2 & U3 & U4 & U5 & \\
\hline Kontrol - & 187 & 164 & 178 & 162 & 197 & $177,6 \pm 14,94$ \\
\hline $\mathrm{P} 1$ & 201 & 189 & 193 & 169 & 161 & $182,6 \pm 16,87$ \\
\hline $\mathrm{P} 2$ & 191 & 176 & 204 & 182 & 169 & $184,4 \pm 13,61$ \\
\hline P3 & 169 & 194 & 182 & 210 & 181 & $187,2 \pm 15,51$ \\
\hline sP4 & 198 & 166 & 176 & 190 & 192 & $184,4 \pm 13,06$ \\
\hline
\end{tabular}

Data dari tabel 4 merupakan kadar glukosa darah mencit setelah diinduksi aloksan. Selanjutnya data tersebut dilakukan uji shapiro wilk menggunakan software SPSS, nilai signifikansinya didapati $\mathrm{p}=>$ 0,05 yang menunjukan data tersebut berdistribusi normal. Data pada tabel tersebut merupakan data pretest dalam metode pre and post test with controlled group design, dibandingkan dengan data pada tabel 4 sebelum diinduksikan aloksan.

Tabel 5. Kadar Glukosa Darah Mencit Setelah Pemberian Ekstrak

\begin{tabular}{lcccccl}
\hline $\begin{array}{l}\text { Perla } \\
\text { Kuan }\end{array}$ & \multicolumn{2}{c}{ Ulangan } & & & & Rata-rata \\
\cline { 2 - 6 } $\begin{array}{l}\text { Kontrol } \\
-\end{array}$ & 191 & 168 & 171 & 170 & $\begin{array}{l}19 \\
4\end{array}$ & $178,8 \pm 12,59$ \\
\hline P1 & 119 & 122 & 115 & 110 & $\begin{array}{l}11 \\
1\end{array}$ & $115,4 \pm 5,12$ \\
\hline P2 & 104 & 101 & 109 & 103 & $\begin{array}{l}10 \\
5\end{array}$ & $104,4 \pm 2,96$ \\
\hline P3 & 132 & 129 & 134 & 138 & $\begin{array}{l}13 \\
3\end{array}$ & $133,2 \pm 3,27$ \\
\hline P4 & 123 & 128 & 122 & 129 & $\begin{array}{l}13 \\
1\end{array}$ & $126,6 \pm 3,91$ \\
\hline
\end{tabular}

Data dari tabel 5 merupakan data posttest yang menunjukkan penurunan kadar glukosa darah mencit setelah pemberian ekstrak, kecuali pada kontrol negatif. Selanjutnya dilakukan uji uji shapiro wilk menggunakan software SPSS, nilai signifikansinya didapati $\mathrm{p}=>0,05$ yang menunjukan data tersebut berdistribusi normal. 
Perbandingan Kadar Glukosa Darah Mencit (Mus musculus)

1. Perbandingan Rata-Rata Peningkatan Kadar Glukosa Darah.

Tabel 6. Rata-Rata Peningkatan

\begin{tabular}{cclll}
\hline $\begin{array}{l}\text { Perla- } \\
\text { kuan }\end{array}$ & N & $\begin{array}{l}\text { Glukosa } \\
\text { Awal } \\
\text { (mg/dl) }\end{array}$ & $\begin{array}{l}\text { Post induksi } \\
\text { aloksan } \\
\text { (mg/d) }\end{array}$ & $\begin{array}{l}\text { Rata-rata } \\
\text { Pening- } \\
\text { katan }\end{array}$ \\
\hline Kontrol- & 5 & $105,8 \pm 8,75$ & $177,6 \pm 14,94$ & $71,8 \%$ \\
\hline P1 & 5 & $105,8 \pm 3,42$ & $182,6 \pm 16,87$ & $72,68 \%$ \\
\hline P2 & 5 & $104,2 \pm 4,26$ & $184,4 \pm 13,61$ & $76,96 \%$ \\
\hline P3 & 5 & $106,6 \pm 5,85$ & $187,2 \pm 15,51$ & $75,6 \%$ \\
\hline P4 & 5 & $104,2 \pm 5,31$ & $184,4 \pm 13,06$ & $76,96 \%$ \\
\hline Total & 25 & & & \\
\hline
\end{tabular}

Data pada tabel 6 menunjukan adanya peningkatan kadar glukosa darah mencit setelah dinduksikan aloksan dari semua kelompok. Selanjutnya data tersebut dilakukan uji shapiro wilk dengan nilai signifikansinya $\mathrm{p}=>0,05$ yang berarti distribusi data normal, kemudian dilakukan uji $t$ berpasangan menggunakan softwere SPSS, nilai signifikansinya $\mathrm{p}=0,000$ yang diinterpretasikan bahwa peningkatan kadar glukosa darah pada mencit sebelum dan sesudah diinduksikan aloksan sangat signifikan.

2. Perbandingan Rata-Rata Penurunan Kadar Glukosa Darah.

Tabel 7. Rata-Rata Penurunan

\begin{tabular}{rclcl}
\hline $\begin{array}{l}\text { Perla- } \\
\text { kuan }\end{array}$ & $\mathbf{N}$ & $\begin{array}{l}\text { Pretest } \\
(\mathbf{m g} / \mathbf{d l})\end{array}$ & $\begin{array}{c}\text { Postest } \\
(\mathbf{m g} / \mathbf{d l})\end{array}$ & $\begin{array}{l}\text { Rata-rata } \\
\text { Penurunan }\end{array}$ \\
\hline P1 & 5 & $182,6 \pm 16,87$ & $115,4 \pm 5,12$ & $35,45 \%$ \\
\hline P2 & 5 & $184,4 \pm 13,61$ & $104,4 \pm 2,96$ & $41,61 \%$ \\
\hline P3 & 5 & $187,2 \pm 15,51$ & $133,2 \pm 3,27$ & $25,5 \%$ \\
\hline P3 & 5 & $184,4 \pm 13,06$ & $126,6 \pm 3,91$ & $29,19 \%$ \\
\hline Total & 20 & & & \\
\hline
\end{tabular}

Data pada tabel 7 menunjukan adanya penurunan kadar glukosa darah mencit setelah perlakuan dengan pemberian ekstrak daun dan akar kumis kucing dengan dosis masing-masing $35 \mathrm{mg}$ dan 50 $\mathrm{mg} / 20 \mathrm{gBB} /$ hari. Data pada tabel tersebut telah dilakukan uji shapiro wilkdengan nilai signifikansinya $\mathrm{p}=>0,05$ yang berarti distribusi data normal, kemudian dilakukan $\mathrm{uji} \mathrm{t}$ berpasangan menggunakan softwere SPSS, nilai signifikansinya $p=0,000$ yang diinterpretasikan bahwa penurunan kadar glukosa darah mencit sebelum dengan sesudah pemberian ekstrak kumis kucing sangat signifikan.

\section{PEMBAHASAN}

Pemberian
meningkatkan kadar gluksan darah pada mencit dalam penelitian telah meningkatkan kadar glukosa darah yang signifikan (Ramadan BK, et al, 2017). (tabel. 4) Aloksan secara selektif merangsang sel $\beta$ pangkreas untuk meningkatkan produksi insulin yang berlebihan, sehingga menyebabkan kerusakan pada sel sel $\beta$ pangkreas. Kerusakan tersebut menyebabkan produksi insulin berkurang yang mengakibatkan peningkatan kadar glukosa darah mencit (Chikezie, 2015). Kerusakan sel $\beta$ pangkreas disebabkan oleh peningkatan reactive oxygen species (ROS), sehingga anti oksidan dalam tubuh mencit tidak mampu menyeimbanginya, kondisi ini disebut stress oksidatif yang dapat merusak sel (Asmat,dkk, 2016). (gambar 2)

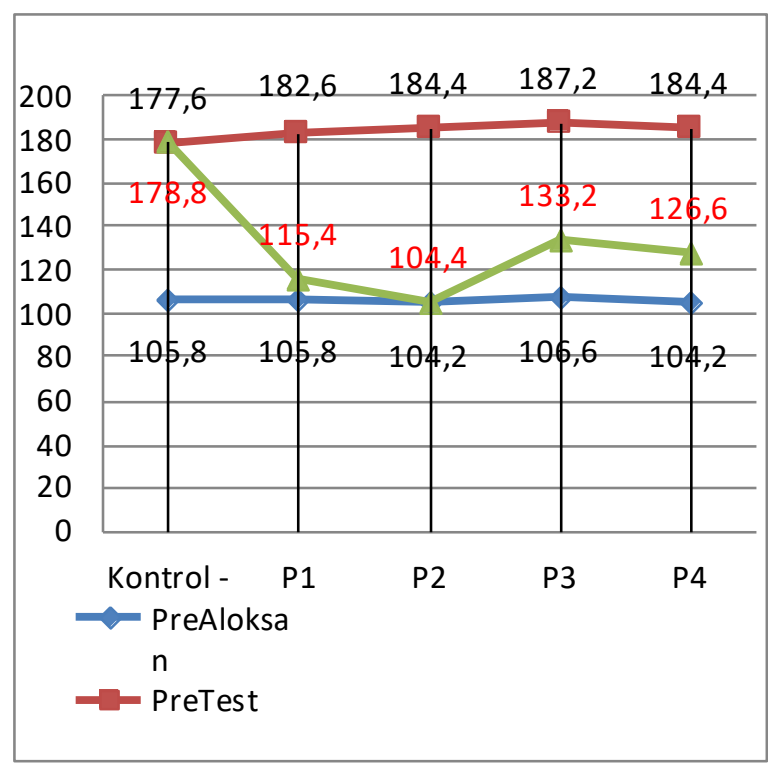

\section{Gambar 2. Grafik Kadar Glukosa Darah Setiap Perlakuan.}

Penelitian menggunakan ekstrak daun dan akar kumis kucing (Orthosiphon stamineus) dengan metode maserasi. Metode ekstraksi maserasi menggunakan maserator, kemudian dilakukan evaporasi untuk memperoleh ekstrak yang lebih murni, metode ini dapat menghemat waktu dan lebih ekonomis (Almatar, dkk, 2014). Ekstrak daun dan akar tumbuhan kumis kucing (Orthosiphon stamineus) selanjutnya dilakukan uji fitokimia untuk membuktikan bahwa terdapat agen anti diabetogenik seperti flavonoid dan saponin. (tabel 2)

Ekstrak akar kumis kucing (Orthosiphon stamineus) dari hasil uji fitokimia tidak mengandung flavonoid dan saponin, akan tetapi hasil penelitian menunjukkan penurunan kadar glukosa darah pada mencit. Kandungan senyawa 
kimia tumbuhan kumis kucing (Orthosiphon stamineus) yang dapat menurunkan kadar glukosa darah tidak hanya flavonoid dan saponin. Terdapat banyak senyawa metabolit lain yang telah terbukti mampu menurunkan kadar glukosa darah baik secara langsung maupun tidak langsung, senyawa lain yang berpotensi dalam menurunkan kadar glukosa darah diantaranya asam rosmarinik, asam sikorat, senyawa monoterpen, diterpen, triterpen dan lain-lain (Fifi, 2015)

Senyawa metabolit pada ekstrak kumis kucing (Orthosiphon stamineus) mampu menurunkan kadar glukosa darah secara biologi. Senyawa metabolit tersebut berfungsi sebagai anti oksidan dan anti inflamasi, sehingga dapat menekan dan memperbaiki kerusakan sel yang ditimbulkan oleh induksi aloksan (Azam, dkk, 2017).

Berdasarkan data dari tabel 7, ekstrak daun kumis kucing (Orthosiphon stamineus) dosis $50 \mathrm{mg} / 20 \mathrm{gBB} / \mathrm{hari}$ mampu menurunkan kadar glukosa darah yang lebih tinggi dengan persentase sebesar $41,61 \%$, di ikuti dengan ekstrak daun kumis kucing (Orthosiphon stamineus) dosis $35 \mathrm{mg} / 20 \mathrm{gBB} / \mathrm{hari}$ dengan persentase $35,45 \%$. Sedangkan ekstrak akar kumis kucing (Orthosiphon stamineus) dosis $50 \mathrm{mg} / 20 \mathrm{gBB} / \mathrm{hari}$ dengan persentase $29,19 \%$. Penurunkan kadar glukosa darah terendah oleh ekstrak akar kumis kucing (Orthosiphon stamineus) dengan dosis $35 \mathrm{mg} / 20 \mathrm{gBB} / \mathrm{hari}$ dengan persentase $25,5 \%$ (Gambar 3).

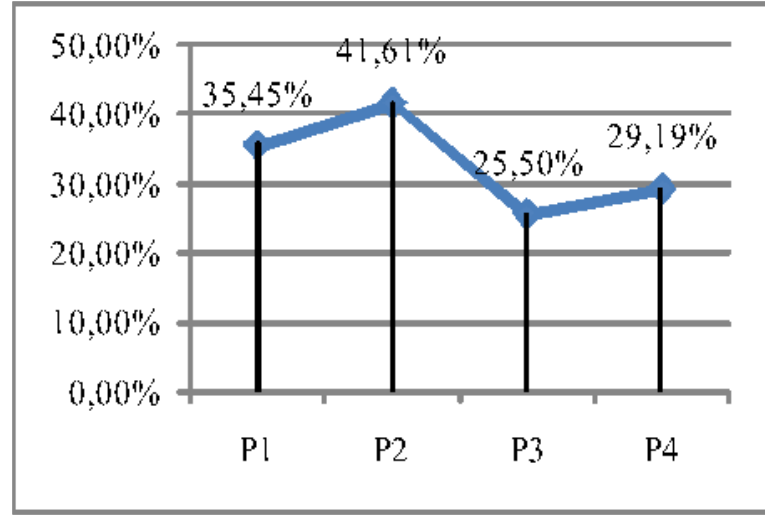

\section{Gambar 3. Grafik Penurunan Kadar Glukosa Darah Mencit Setelah Pemberian Ekstrak Kumis Kucing (Orthosiphon stamineus)}

Berdasarkan gambar 3, penurunan kadar glukosa darah yang lebih tinggi disebabkan oleh kandungan senyawa metabolit di dalam daun kumis kucing (Orthosiphon stamineus) yaitu flavonoid dan saponin yang tidak terdapat didalam akarnya. Kedua senyawa tersebut mampu mensintesiskan siklus asam tricarboxylic (TCA) untuk meningkatkan penggunaan glukosa darah yang dapat diubah menjadi energi (Febriani, dkk, 2017)

\section{KESIMPULAN}

Hasil penelitian tentang uji efektifitas ekstrak etanol $96 \%$ daun dan akar kumis kucing (Orthosiphon stamineus) terhadap penurunan kadar glukosa darah pada mencit dapat disimpulkan bahwa:

1. Ekstrak etanol $96 \%$ daun kumis kucing (Orthosiphon stamineus) dosis $50 \mathrm{mg} / 20 \mathrm{gBB} /$ hari berhasil menurunan kadar glukosa darah sebanyak $41,61 \%$ dan merupakan penurunan kadar glukosa darah mencit tertinggi.

2. Ekstrak etanol $96 \%$ daun kumis kucing (Orthosiphon stamineus) lebih efektif dibandingkan dengan ekstrak etanol 96\% akar kumis kucing (Orthosiphon stamineus) dalam menurunkan kadar glukosa darah mencit.

3. Senyawa flavonoid dan saponin memberikan efek penurunan kadar gwlukosa darah yang lebih tinggi pada mencit.

\section{DAFTAR PUSTAKA}

Abdelsalam AM, Al-damegh MA. (2018). Research Article. Antidiabetic and Immunoprophylactic Effects of Camel Milk Filtrate and Bitter Gourd (Momordica charantia ) Juice Against Alloxan-induced Oxidative Stress and Diabetes in Rats. International Journal of Pharmacology. Vol. 14: 397-406.

Adnyana IK, Setiawan F, Insanu M. (2013). From Ethnopharmacology To Clinical Study Of Orthosiphon Stamineus Benth. International Journal of Pharmacy and Pharmaceutical Sciences. Vol. 5. No. 3.

Almatar M, Ekal H, Rahmat Z. (2014). A glance on medical applications of Orthosiphon stamineus and Some of Its Oxidative Compounds. International Journal Pharmaceutical Sciences Review and Research. Vol.24, No.2, hh 83- 88.

American Diabetes Association (ADA). 
(2017). Standard of medical care in diabetes - 2017. Diabetes Care. The journal of clinical and applied research and education. Vol. 40. Supp.1

Asmat U, Abad K, Ismail K. (2015). Diabetes Mellitus and Oxidative Stress-A Concise Review. Saudi Pharmaceutical Journal.

2016;24(5):547-553.

doi:10.1016/j.jsps.2015.03.013.29.

Chikezie PC, Ojiako OA, Ogbuji AC. Oxidative Stress in Diabetes Mellitus. International Journal of Biological Chemistry. 9(3):92-109. doi:10.3923/ijbc.2015.92.109.

Azam AA, Pariyani R, Ismail IS, et al. (2017). Urinary Metabolomics Study on the Protective Role of Orthosiphon stamineus in Streptozotocin Induced Diabetes Mellitus in Rats Via $1 \mathrm{H}$ NMR Spectroscopy. BMC Complement Alternative Medicine.

Chikezie P. (2014). Blood Glucose Level and Lipid Profile of Alloxan- Induced Hyperglycemic Rats Treated with single and combinatorial herbal formulation. Journal of traditional complementary medicine. Vol. 6. Ed. 2.

Cho, N.H, Shaw, J.E, et. Al. (2018). IDF Diabetes Atlas: Global estimates of diabetes prevalence for 2017 and projects for 2045. International Diabetes Federation. Diabetes research and clinical practice 138 .

Fauzan Ih. uji Efek Ekstrak Etanol 70\% Daun Kumis Kucing (Orthosiphon stamineus) terhadap Kadar Glukosa Darah Tikus Putih Jantan Galur Wistar Yang Diinduksi Aloksan. Fakultas Kedokteran unifersitas muhammadiyah surakarta. 2017.

Febriani Y, Fidrianny I, June M, June $M$. (2017). Research Journal of Pharmaceutical, Biological and Chemical Sciences Isolation of Two Methoxy Flavonoid Compounds from Kumis Kucing (Orthoshipon stamineus) a Popular Plant in Indonesian Herbal Medicine Jamu. Research Journal of

Pharmaceutical, Biological and Chemical Sciences, Biol Chem Sci. 2017;8(1640): 1640-1646.

Fifi K. (2015). Analisis Struktur Sekretori, Histokimia, Fitokimia, dan Potensi Antibakteri dari Beberapa Tumbuhan
Obat Antiinfeksi di Taman Wisata Alam Telaga Warna Bogor. Institut Pertanian Bogor.

Ighodaro OM, Adeosun AM, Akinloye OA. (2017). Alloxan-Induced Diabetes, a Common Model for Evaluating the Glycemic-Control Potential of Therapeutic Compounds and Plants Extracts in experimental Studies. Medicina. 53(6):365-374. doi:10.1016/j.medici.2018.02.001.

Kemenkes Republik Indonesia. (2014). Situasi dan Analisis Diabetes. Pusat Data dan Informasi Kementerian Kesehatan Republik Indonesia. 2.doi:24427659.

Kemenkes Republik Indonesia. (2018). Hasil utama Riskesdas 2018. Badan penelitian dan pengembangan kesehatan.

Lee HJ, Choi YJ, Park SY, et al. (2015). Hexane extract Of Orthosiphon Stamineus Induces Insulin Expression and Prevents Glucotoxicity In INS-1 Cells. Diabetes Metabolism Journals. 2015;39(1):51-58. doi:10.4093/dmj.2015.39.1.51.

Mohamed EA, Ahmad M, Ang LF, Asmawi MZ, Yam MF. (2015). Evaluation of? Glucosidase Inhibitory Effect of $50 \%$ Ethanolic Standardized Extract of Orthosiphon stamineus Benth in Normal and Streptozotocin-Induced Diabetic Rats.Hindawi Publishing Corporation. doi:10.1155/2015/754931.

PERKENI. Konsensus Pengendalian dan Pencegahan Diabetes Melitus Tipe 2 di Indonesia 2015.; 2015. doi:10.1017/CBO9781107415324.004.

Ramadan BK, Schaalan MF, Tolba AM. (2017). Hypoglycemic and Pancreatic Protective Effects of Portulaca Oleracea Extract in Alloxan Induced Diabetic Rats. BMC Complement and Alterenative Medicine. Vol.17. Ed.1:110. doi:10.1186/s12906-016-1530-1.

Ri W, Lph DIU, Citrus H, et al. (2015)

Ekstraksi Maserasi Oleoresin Daun Jeruk Purut (Citrus hystrix DC): Optimasi Rendemen Dan Pengujian Karakteristik Mutu. Agritech. Vol. 35. Ed.2:178-184.

Saputri Me. (2017). Uji Efek Ekstrak Etanol 70\% Akar Kumis Kucing (Orthosiphon stamineus) terhadap Kadar Glukosa Darah Tikus Putih Jantan Galur Wistar (Rattus Norvegicus) Yang Diinduksi Aloksan. Fakultas Kedokteran 
Universitas Muhammadiyah Surakarta. Singh MK, Gidwani B, Gupta A, et al. (2015).

$A$ review of the medicinal plants of genus Orthosiphon (Lamiaceae).

International Journal of Biological

Chemistry. Vol. 9. Ed. 6. :318-331.

doi:10.3923/ijbc.2015.318.331.

WHO. (2016)-Diabetes-Facts-and-Numbers Indonesian. 